\title{
REFERENCES
}

Allcroft, R. (1946). Nature, Lond., 158, 796.

Allcroft, R. (1949). (In preparation.)

Bennetts, H. W. \& Beck, A. B. (1942). Bull. Coun. Sci. industr. Res. Aust. no. 147.

Bennetts, H. W. \& Chapman, F. E. (1937). Aust. vet. F. 13, 138.

Bennetts, H. W. \& Hall, H. T. B. (1939). Aust. vet. F. 15, 152.

Brouwer, E., Frens, A. M., Reitsma, P. \& Kalisvaart, C. (1938). Versl. RijkslandbProefst. Hoorn, no. 44 (4) C., p. 267.

Cunningham, I. J. (1944), N.Z. F. Agric. 69, 559.

Cunningham, I. J. (1946). N.Z. F. Sci. Tech. 27, sect. A, p. 381 .

Dick, A. T. \& Bull, L. B. (1945). Aust. vet. F. 21, 70.

Eden, A. \& Green, H. H. (1940). Biochem. F. 34, 1202.

Ferguson, W. S. (1943). F. agric. Sci. 33, I 16.

Ferguson, W. S., Lewis, A. H. \& Watson, S. J. (1943). F. agric. Sci. 33, 44.

Hunter, A. H., Eden, A. \& Green, H. H. (1945). F. comp. Path. 55, 19.

Innes, J. R. M. \& Shearer, G. D. (1 940). F. comp. Path. 53, I.

Jamieson, S. \& Allcroft, R. (1949). (In preparation.)

Jamieson, S. \& Russell, F. C. (1946). Nature, Lond., I57, 22.

Melchers, W. J. \& Gerritsen, H. J. (1944). Koper als Onmisbaar Element voor Plant en Dier. Wageningen: Gebr. Zomer en Keuning.

Neal, W. M., Becker, R. B. \& Shealy, A. L. (1931). Science, 74, 418.

Newcomer, H. S. (1923). F. biol. Chem. 55, 569.

Perrin, D. D. (1946). N.Z. Y. Sci. Tech. 27, sect. A, p. 396.

Sjollems, B. (1933). Biochem. Z. 267, 151.

Sjollema, B. (r938). Biochem. Z. 295, 372.

\section{Haematuria in Pyridoxin-Deficient Rats}

\author{
By L. R. C. AGNEW \\ Rowett Research Institute, Bucksburn, Aberdeenshire
}

(Received 3 May 1949)

During studies on antibody production in pyridoxin-deficient hooded rats (Agnew \& Cook, 1948-9), gross macroscopic haematuria was noted in several animals fed a pyridoxin-deficient diet, but not in corresponding litter-mate inanition-control (paired-weighed) rats, or in rats fed the complete diet ad lib. It was impracticable at that time to investigate the matter fully, and only a preliminary note of the incidence and duration of these macroscopic haematurias was published (Agnew, I948-9). As haematuria has not been reported in any of the numerous recent papers from the United States on pyridoxin deficiency, and only Birch (1938) appears to have commented on this matter, it seemed of interest to make a detailed study of the incidence, duration and severity of the haematuria which was so regularly observed in our pyridoxindeficient rats. The effect of the haematuria on the peripheral blood picture (red cell count and haemoglobin content) was also studied, as well as the effect of giving pyridoxin to rats with well-established haematuria. Finally, possible strain differences in susceptibility to haematuria were sought by observing the effect of pyridoxin deficiency in Wistar albino rats fed the same diet as the hooded Lister rats. 
METHODS

\section{Animals used, their diet and management}

The animals used were (I) hooded Lister rats (Rowett Institute strain), and (2) albino rats obtained from the Agricultural Research Council Field Station, Compton; these were originally derived by Glaxo Laboratories Ltd. from brother-sister matings of Wistar rats. Each experiment in the present series involved the use of several trios of litter-mate weanling rats of the same sex and approximately the same weight, each trio of animals being arranged thus:

rat no. I received the experimental diet ad lib, with all vitamin supplements;

rat no. 2 received the diet $a d$ lib. with all vitamin supplements except pyridoxin;

rat no. 3 was paired-weighed with rat no. 2 but was given pyridoxin; i.e. it received the amount of diet required to keep it equal in weight to rat no. 2.

Four experiments, each with six trios of rats (three male, three female) arranged as above, were set up as in Table $x$. The synthetic diet used has already been described (Agnew \& Cook, 1948-9).

Table I. Plan of experiments to test the effects on the incidence and course of haematuria of various supplements to a synthetic pyridoxin-deficient diet for rats

\begin{tabular}{cccl} 
Exp. no. & Strain of rat & $\begin{array}{c}\text { No. of rat } \\
\text { trios used }\end{array}$ & \multicolumn{1}{c}{$\begin{array}{c}\text { Nature and amount of fat in synthetic pyridoxin- } \\
\text { deficient diet (Agnew \& Cook, 1948-9) }\end{array}$} \\
I & Lister, hooded & $6\left(3 \delta^{3}, 3 \%\right)$ & Margarine, 5\% \\
2 & Lister, hooded & $6\left(3 \delta^{\circ}, 3 \%\right)$ & Lard, $5 \%$ \\
3 & Lister, hooded & $6\left(30^{\circ}, 3 \%\right)$ & Margarine, $5 \%$ with $750 \mathrm{mg}$. linoleic acid/100 g. diet \\
4 & Wistar, albino & $6\left(3 \delta^{\circ}, 3 \%\right)$ & Margarine, $5 \%$
\end{tabular}

The animals were housed in individual cages with wide wire-screened bases; they had unlimited access to water and were weighed daily, except on Sundays.

The only readily available linoleic acid for use in Exp. 3 (Table r) was technical linoleic acid (British Drug Houses Ltd.), and it is possible that this substance is too impure for nutritional studies; this point is discussed later.

Rats, except those used for blood studies, were killed with coal gas alone. In all but two instances (Table 2, trio $\mathrm{E}$; Table 6, trio $\mathrm{F}$ ), when a rat died the remaining members of the trio were killed. The heart and both kidneys were carefully dissected out. The heart was sliced and any blood removed from its chambers; thereafter it and both kidneys were weighed and placed in $2.0 \%$ formaldehyde (five parts commercial formalin plus ninety-five parts $0.9 \%$ saline) for subsequent histological examination.

Rats of the trios selected for blood studies were anaesthetized with ether, and blood was obtained, by cutting the left axillary vein, for red cell counts and haemoglobin estimations (Haldane-Gower method). These animals were then killed with coal gas, and the hearts and kidneys were dealt with as described above. The colour index was calculated from the formula given by Evans (1945): $\frac{\text { Haemoglobin } \% \text { (Haldane) } \times 5}{\text { Millions of cells } / \text { cu.mm. } \times 100}$. 
This formula, based on human standards of normality, gave 0.59 for normal (i.e. ad lib. control) rats of this experiment (Table 6). Lower figures than this indicate the extent of the microcytosis and hypochromasia seen in the pyridoxin-deficient rats (Table 6).

\section{Collection of urine and detection of haematuria}

A simple, rapid method for the examination of urine for red blood cells had to be devised as it was impracticable to provide a metabolism cage unit for each rat. A piece of white filter-paper (Whatman no. I) was placed beneath each cage, usually every alternate day, and $\mathrm{I} \mathrm{hr}$. or so later the urine splashes on the paper were examined for blood by naked-eye inspection and by the benzidine reaction. The latter was used only as a screening test; if it was negative blood was assumed to be absent from the urine. A positive result, however, was interpreted as an indication that blood might be present, and that the urine should be examined microscopically. Sufficient urine for this purpose was usually obtained by approaching the rat gently, lifting it by the scruff of the neck, and chilling the abdomen with a gauze pad soaked with ether. Blood in the urine detectable by the naked eye is referred to as 'macroscopic haematuria' to distinguish it from 'microscopic haematuria' detected by the benzidine reaction and microscopy.

\section{RESULTS}

\section{Incidence and duration of haematuria}

Exp. I. Hooded rats; $5 \%$ margarine

The results are summarized in Table 2. Haematuria of variable duration was observed in all the pyridoxin-deficient animals but not in any of the ad lib. or inanition controls. The mean time of onset of haematuria was 27 days (range 24-34) after the pyridoxindeficient diet was first fed. The bleeding persisted in trios A, B and D until the animals died or were killed. The haematuria lasted 66 days in trio $\mathrm{F}$ and only 7 days in trio $\mathrm{C}$. The pyridoxin-deficient rat of trio $\mathrm{E}$ died after 64 days on the experimental diet, having had haematuria for the last 40 days of this period. The remaining members of this trio were not killed at this time and for this reason figures for this trio were omitted in calculating the means given in Table 2. As a matter of interest the inanition-control rat of this trio was given the pyridoxin-deficient diet beginning 5 days after the pyridoxindeficient rat died. Within 5 days it developed haematuria, which persisted until the animal was killed, along with the ad lib. control rat, $\mathrm{r}_{4} 4$ days after it first showed haematuria.

An attempt was made to determine whether ascorbic acid and rutin (a flavonol glycoside), which are thought to counteract bleeding tendencies, would influence the haematuria. The pyridoxin-deficient rat of trio B had severe haematuria and was given a course of ascorbic acid (50 mg. daily by mouth) from the rorst day on the deficient diet, for 17 days. Beginning 2 days later, $60 \mathrm{mg}$. of rutin were given daily for 9 days. Neither substance modified the severity of the haematuria in any way. Pyridoxin was then fed to this rat and the body-weight at once increased, although haematuria continued as before until the rat, along with the control animals of the trio, was killed 28 days later. 


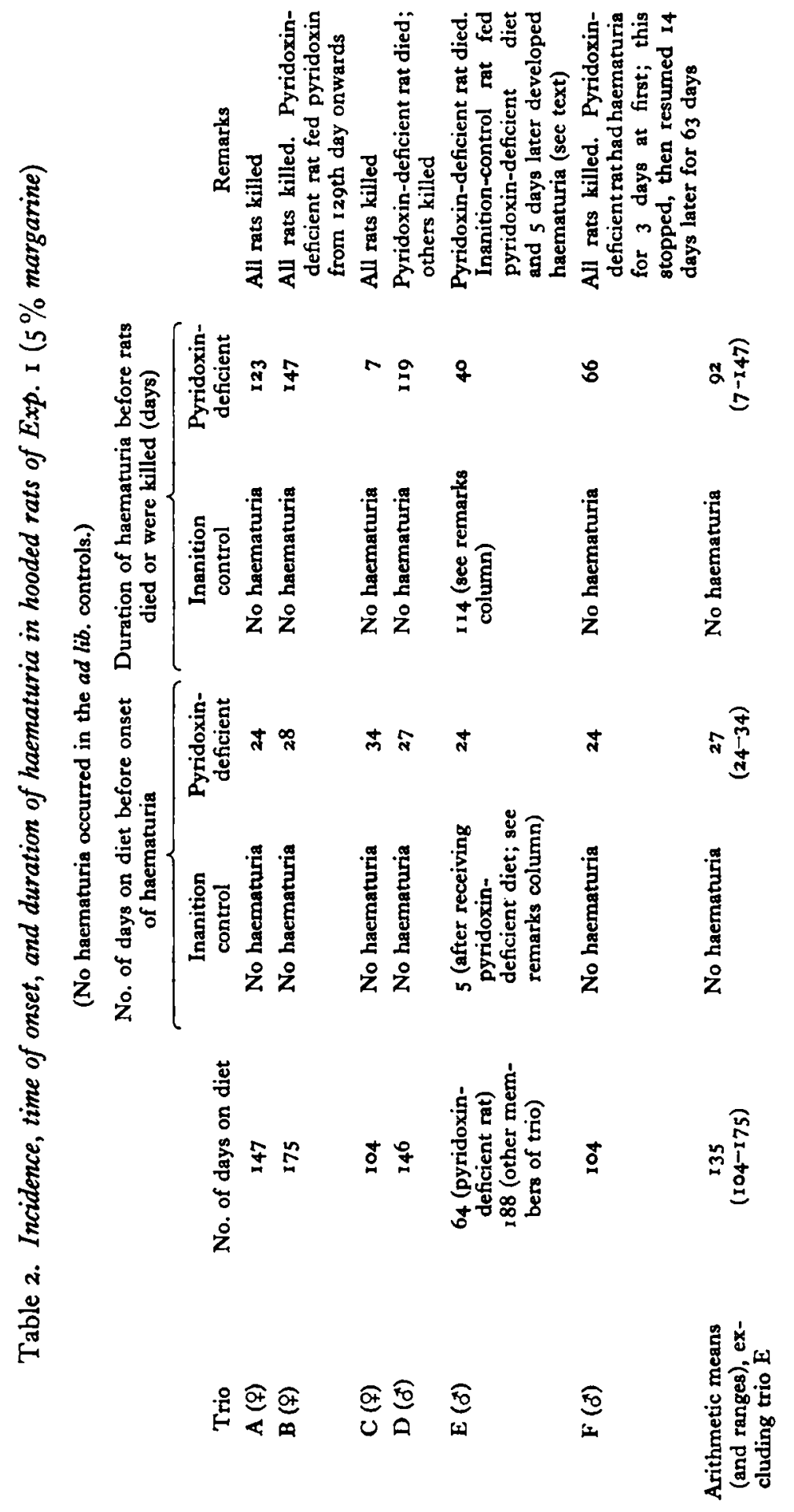


Exp. 2. Hooded rats; $5 \%$ lard

The results are summarized in Table 3. As in Exp. I, haematuria of variable duration was observed in all the pyridoxin-deficient animals, but not in any of the ad lib. or inanition controls. The mean time of onset was 26 days (range 23-34). In trios A-D and $F$ the bleeding persisted until the animals died or were killed. The pyridoxindeficient rat in trio $\mathrm{E}$ had haematuria for only 8 days at first; bleeding resumed 6 days later and persisted until the animal was killed. Pyridoxin was fed to the pyridoxindeficient rats, which had severe haematuria, of trios B and C from the Io5th day until the animals were killed. Although the body-weight at once increased markedly no modification of the duration or severity of the haematuria was observed, and bleeding persisted until the animals were killed.

\section{Table 3. Incidence, time of onset, and duration of haematuria in the} pyridoxin-deficient hooded rats of Exp. $2(5 \%$ lard $)$

(No haematuria occurred in the ad lib. and inanition controls.)

\begin{tabular}{|c|c|c|c|c|}
\hline Trio & $\begin{array}{l}\text { No. of days } \\
\text { on diet }\end{array}$ & $\begin{array}{c}\text { No. of days } \\
\text { on diet before } \\
\text { onset of } \\
\text { haematuria }\end{array}$ & $\begin{array}{l}\text { Duration of } \\
\text { haematuria } \\
\text { before rats died } \\
\text { or were killed } \\
\text { (days) }\end{array}$ & Remarks \\
\hline A $q$ & 130 & 23 & 107 & All rats killed \\
\hline B $q$ & 140 & 25 & II 5 & $\begin{array}{l}\text { All rats killed. Pyridoxin- } \\
\text { deficient rat fed pyridoxin } \\
\text { from ro5th day until death }\end{array}$ \\
\hline C $q$ & 134 & 25 & 109 & $\begin{array}{l}\text { All rats killed. Pyridoxin- } \\
\text { deficient rat fed pyridoxin } \\
\text { from ro5th day until death }\end{array}$ \\
\hline $\mathrm{D} \sigma$ & 124 & 25 & 99 & $\begin{array}{l}\text { Pyridoxin-deficient rat } \\
\text { died; others killed }\end{array}$ \\
\hline E ठै & I I I & 34 & 71 & $\begin{array}{l}\text { All rats killed. Pyridoxin- } \\
\text { deficient rat had haems- } \\
\text { turia for } 8 \text { days at first; } \\
\text { this stopped, then re- } \\
\text { sumed } 6 \text { days later for } \\
63 \text { days }\end{array}$ \\
\hline $\mathbf{F} \delta$ & 110 & 25 & 85 & All rats killed \\
\hline $\begin{array}{l}\text { tic means } \\
\text { (nges) }\end{array}$ & $\begin{array}{c}125 \\
(110-140)\end{array}$ & $\begin{array}{c}26 \\
(23-34)\end{array}$ & $\begin{array}{c}98 \\
(7 x-155)\end{array}$ & \\
\hline
\end{tabular}

Exp. 3. Hooded rats; $5 \%$ margarine plus linoleic acid

The results are summarized in Table 4. Haematuria of variable duration was observed in all the pyridoxin-deficient rats and, most unexpectedly, in five of the six corresponding ad lib. control rats. One inanition-control rat (trio F) died 49 days after the start of the experiment, but haematuria was not observed in this or in any of the other inanition-control rats. Haematuria appeared later in the pyridoxin-deficient rats than in Exps. 1 and 2, the mean time of onset being 76 days (range $4 \mathrm{I}-105$ ). The haematuria was intermittent in the pyridoxin-deficient rats of trios $C$ and $F$. The mean 
(2)

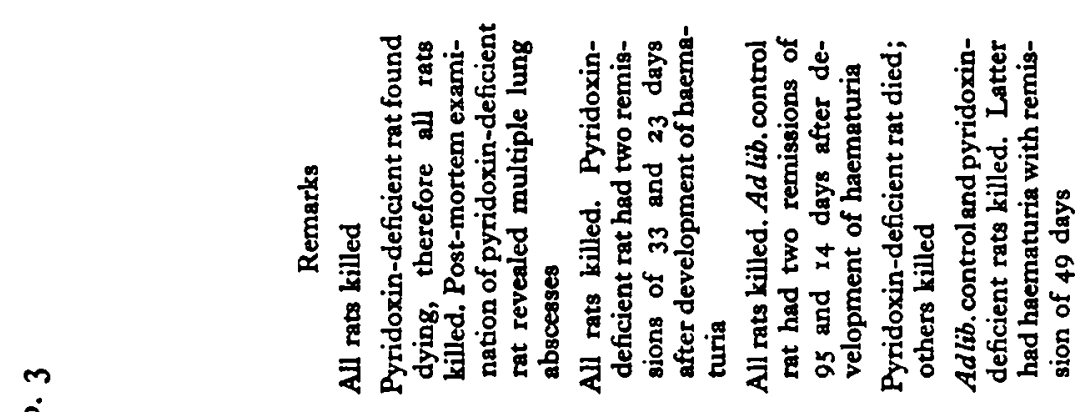

究

$q$

5

กิ ก

ผ

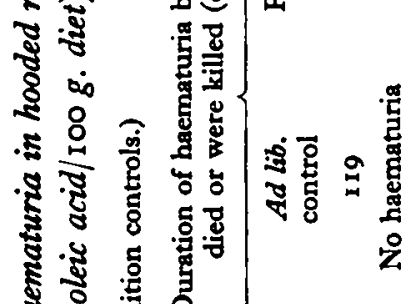

$m$ 뉴 웛

n)

i 2 \%

in $2 \%$

₹

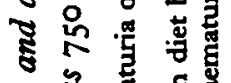

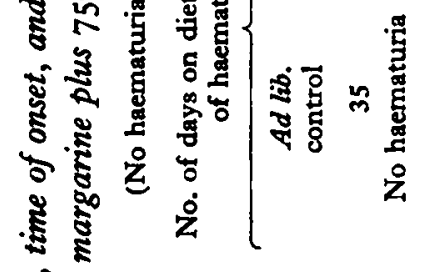

\& 8 म

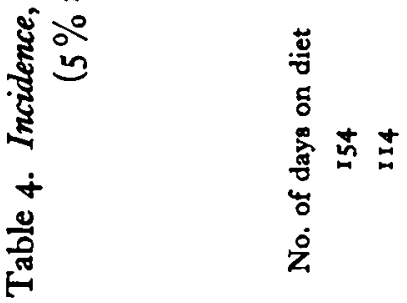

安壳

논

in

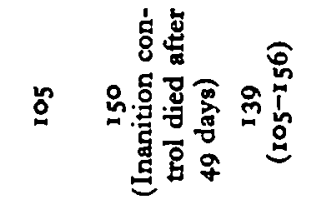

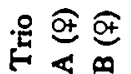

O 0 तु

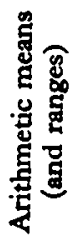


time of onset of the haematuria observed in the ad lib. control rats was 60 days (range 30-147). The bleeding was intermittent in two cases (trios $C$ and F), and in three cases (trios A, E and F) continued until the rats died or were killed.

\section{Exp. 4. Albino rats; $5 \%$ margarine}

The results are summarized in Table 5. Haematuria was observed in only two animals. Microscopically (never with the naked eye) blood was noted intermittently in the urine of the ad lib. control rat and of the inanition-control rat of trio B 94 and 9 I days respectively after the start of the experiment. The ad lib. control rat had haematuria for a total of 15 days, and the inanition-control rat for 4 days. Unfortunately, these rats were accidentally killed during an attempt to stimulate urine secretion by carbachol, but they would have been killed a day or two later in any case as it is doubtful if, for reasons discussed below, the pyridoxin-deficient rat of the trio would have lived much longer.

\section{Severity of haematuria}

In Exps. I-3 the haematuria was generally severe and the paper below the cages was very often blood stained. In an occasional animal (e.g. Exp. 1, trio C) bleeding was detected only by the benzidine reaction and confirmed by microscopic examination of the urine. Severe macroscopic haematuria was often preceded and succeeded by a variable period of bleeding detectable only microscopically. The duration of macroscopic haematuria was extremely variable, ranging from only I day to several weeks. In an earlier experiment (Agnew, I948-9) the usual duration of macroscopic haematuria in seven pyridoxin-deficient rats was $4-6$ days (limits $I^{-13}$ days), but the duration of haematuria was probably far longer since, in these experiments, the benzidine reaction and microscopy were not employed to detect non-macroscopic bleeding.

\section{Haematological examination}

Table 6 summarizes the observations made of the red cell count and haemoglobin percentage of eight trios (four male, four female) of rats that had been fed the experimental diet for periods ranging from 104 to 156 days. The results indicate that pyridoxin deficiency caused a significant $(P<0.001)$ increase in the red cell count, a significant $(P<0.02)$ decrease in haemoglobin percentage, and a significant $(P<0.0001)$ lowering of the colour index. Microcytosis has been reported in pyridoxin-deficient rats by Carpenter \& Kodicek (1948-9), and the present results confirm their findings.

It is of interest to note the effect of administration of pyridoxin on the blood picture of deficient animals (Table 7). Statistical analysis of data in Tables 6 and 7 indicated that differences due to sex and differences due to litter effect were negligible, and thus comparison of the red cell count, haemoglobin percentage and colour index of these trios was permissible. As mentioned above, the duration and severity of haematuria in the trios listed in Table 7 were not influenced by pyridoxin administration. It would seem, therefore, that the severe haematuria observed in these rats had not affected the blood picture, as administration of pyridoxin caused a return of the red cell count and haemoglobin percentage to normal and, curiously, a just significant $(P<0.05)$ elevation 


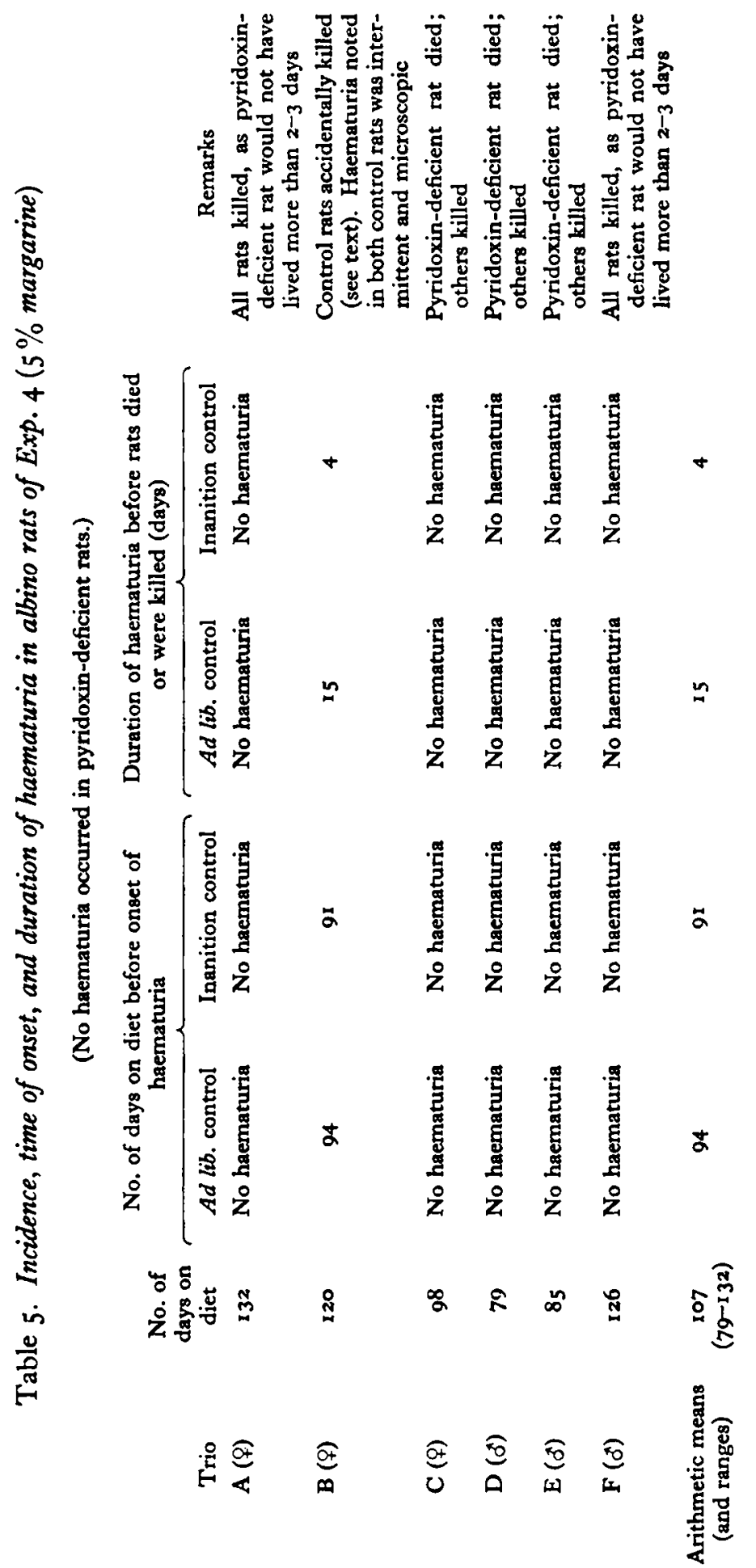


of the colour index above normal. As already noted (p. 219), the colour index of the rats listed in Tables 6 and 7 is calculated from a formula for man and is thus to be regarded only as a relative measurement. Compared with 0.59 for normal rats (Table 6), the figure of 0.38 indicates that the red cells of the pyridoxin-deficient rats were hypochromic and microcytic.

\section{Exp. I. Hooded rats; $5 \%$ margarine}

\section{Organ weights}

The results are summarized in Table 8 , from which trio $\mathrm{E}$ (see Table 2) has been omitted. Although the pyridoxin-deficient rat of trio $B$ received pyridoxin (see Tables 2 and 7), this trio is included in Table 8 as this treatment had no effect on the haematuria. The kidneys of the pyridoxin-deficient rats were not significantly heavier than those of the inanition-control rats, although the observed differences were suggestive, and just reached significance $(P<0.05)$ when the kidney weights of the ad lib. and inanition controls were combined.

The heart weights of trios $C$ and $F$ were not recorded. The hearts of the pyridoxindeficient rats of trios $\mathrm{A}, \mathrm{B}$ and $\mathrm{D}$ were significantly $(P<0.05)$ heavier than those of the corresponding ad lib. and inanition controls.

\section{Exp. 2. Hooded rats; $5 \%$ lard}

The results are summarized in Table 8. The pyridoxin-deficient rats of trios $\mathrm{B}$ and $\mathrm{C}$ had received pyridoxin (see Tables 3 and 7), but these trios are included in Table 8 as this treatment had no effect on the haematuria. The kidneys of the pyridoxin-deficient rats were significantly $(P<0.01)$ heavier than those of the ad lib. and inanition-control rats.

The heart weights of trios $E$ and $F$ were not recorded. The hearts of the pyridoxindeficient rats of trios A-D just failed to be significantly heavier than those of the inanition-control rats, but this might be ascribed to one chance high value in the latter group (trio C).

\section{Exp. 3. Hooded rats; $5 \%$ margarine plus linoleic acid}

The results are summarized in Table 8 , from which trio $F$ (see Table 4) has been omitted. The kidneys of the pyridoxin-deficient rats were significantly $(P<0.0 \mathrm{I})$ heavier than those of the inanition and ad lib. controls. The hearts of the pyridoxindeficient rats were also significantly $(P<0.05)$ heavier than those of the inanition and ad lib. controls.

\section{Exp. 4. Albino rats; $5 \%$ margarine}

The results are summarized in Table 8 . The kidneys of the pyridoxin-deficient rats were significantly $(P<0.01)$ heavier than those of the inanition and ad lib. controls. The kidneys of the inanition-control rats were significantly $(P<0.01)$ heavier than those of the ad lib. controls. The hearts of the pyridoxin-deficient rats were significantly $(P<0.01)$ larger than those of the inanition and ad lib. controls. 


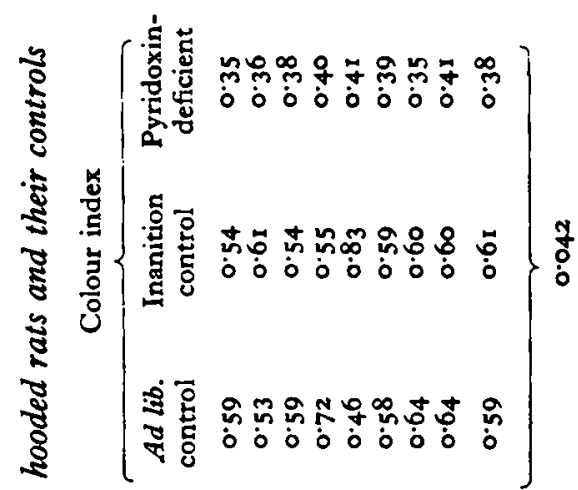

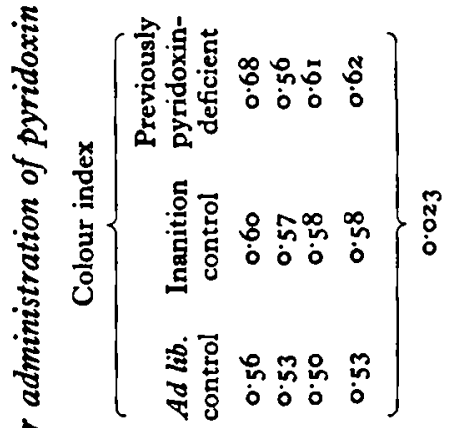

है

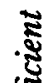

焉

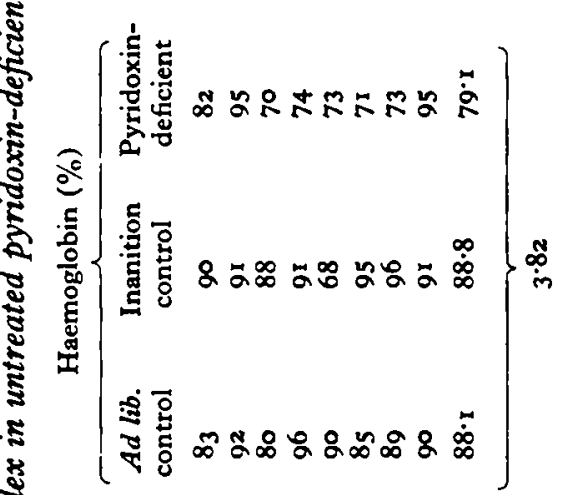

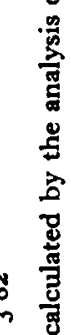

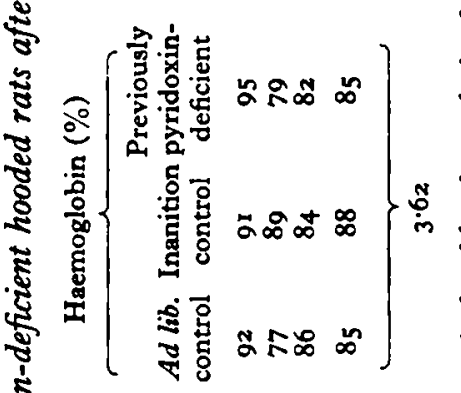

迎

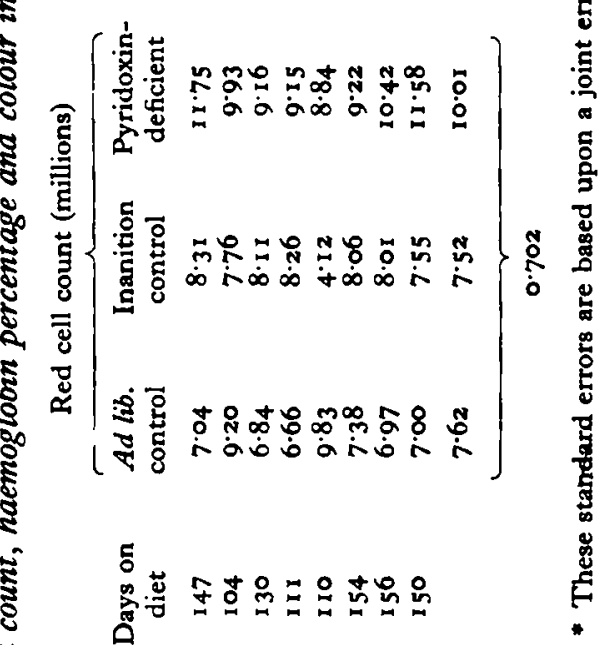

ชี

ชั:

के

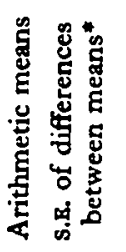

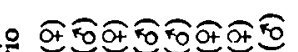

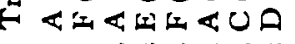

Han Namm

E

है

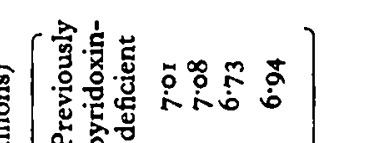

$\{$.

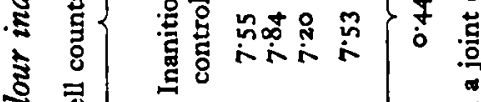

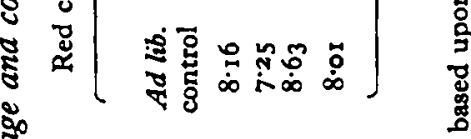

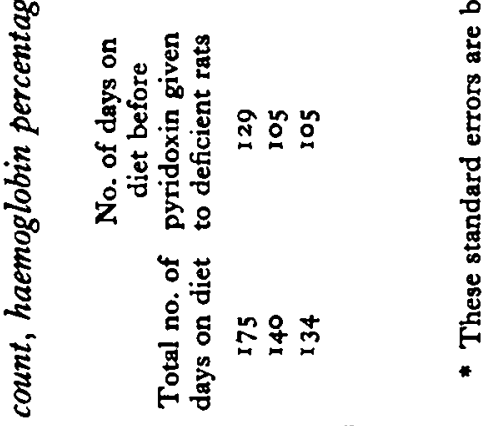

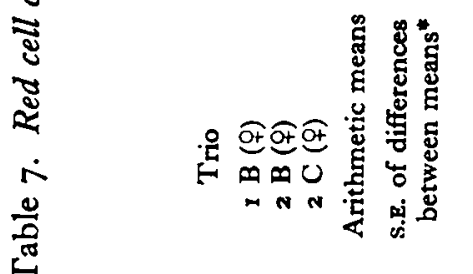


Vol. 3
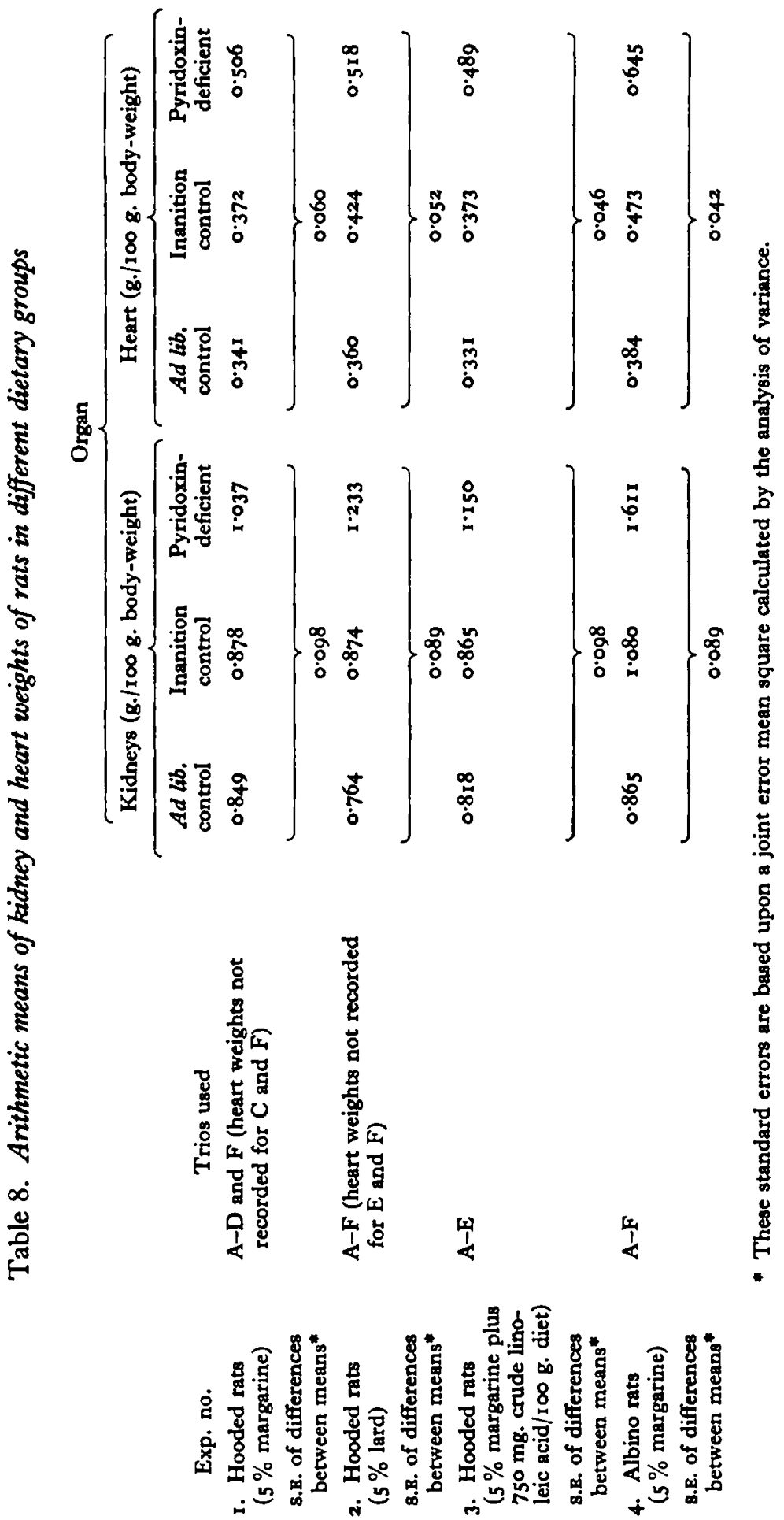
Statistical analysis indicated that in all the above experiments sex did not influence the organ weights. No significant differences in heart and kidney weights of comparably treated rats in Exps. I-3 were observed, but the albino-rat kidneys and hearts were significantly $(P<0.01)$ heavier than those of comparably treated rats in any of the other experiments.

\section{Renal lesions}

Interesting renal lesions, ranging from gross macroscopic pitting and scarring to changes visible only microscopically, were observed in most of the rats that had had haematuria; they will be reported in detail later.

\section{Strain differences}

The most striking difference between pyridoxin-deficient rats of the hooded and albino strains, apart from the failure of the albinos to develop haematuria, lay in the rate of development and severity of acrodynia-like skin lesions. Hooded rats fed the deficient diet did not develop skin lesions until after 4-5 months, the skin changes then observed being dry scaling of the dorsa of the hind paws and, later, dry necrosis of the ear tips. Usually the fur became rather unkempt and in one animal one side of the nose became denuded of fur. Fits were noted in a few of the animals that had been at least 4 months on the deficient diet.

Within 50 days, however, four of the six pyridoxin-deficient albino rats developed severe acrodynia-like lesions. The paws became red, hot and swollen; the fur was unkempt and occasionally 'spiky'; a bloody exudate covered the snout; and there was denudation of fur about the eye. Once started, these acrodynia-like lesions persisted. In two of the six pyridoxin-deficient albino rats the lesions did not become marked until they had received the deficient diet for about 100 days. Three of the more severely affected animals died after relatively short periods on the diet (Table 5). The remaining three trios were killed (one accidentally), but on each occasion it was doubtful if the pyridoxin-deficient rat would have survived more than another day or two. As indicated above, haematuria was not observed in any of the pyridoxin-deficient albino rats, although noted for variable periods in all of the pyridoxin-deficient hooded rats. The possible significance of the mild microscopic haematurias that were observed in two of the albino-control rats (Table 5) will be discussed below.

No striking differences were noted between the growth curves of the albino and hooded pyridoxin-deficient rats. However, it seemed possible that the hooded rats did not develop severe acrodynia because their intestinal bacteria synthesized enough pyridoxin to protect them. Table 9 summarizes the results of an experiment designed to test one aspect of this hypothesis. Nine male litter-mate hooded rats were divided into trios in the usual way. The pyridoxin-deficient rats of trios 2 and 3 were given orally $5 \mathrm{mg}$. of deoxypyridoxin (the potent antivitamin of pyridoxin) in $0.5 \mathrm{ml}$. distilled water by stomach tube on ten occasions for trio 2 and seven occasions for trio 3,50 and $35 \mathrm{mg}$. being given over periods of 18 and 14 days respectively. The ad lib. and inanition controls of the trios were given $0.5 \mathrm{ml}$. distilled water orally by tube on the occasions when deoxypyridoxin was given to the pyridoxin-deficient 
animals. The rats receiving deoxypyridoxin lost weight (Fig. I), and severe acrodynialike lesions, particularly of the forepaws, developed which were comparable to those hitherto noted only in the albino rats. Unkempt fur and a blood-stained exudate about

Table 9. Effect of deoxypyridoxin administration on kidney and heart weights of hooded rats on pyridoxin-deficient diet

\begin{tabular}{|c|c|c|c|c|c|c|c|c|}
\hline \multirow[b]{3}{*}{ Trio } & & \multicolumn{6}{|c|}{ Organ } & \multirow[b]{3}{*}{ Remarks } \\
\hline & \multirow{2}{*}{$\begin{array}{l}\text { No. of } \\
\text { days on } \\
\text { diet }\end{array}$} & \multicolumn{3}{|c|}{$\begin{array}{c}\text { Kidneys } \\
\text { (g./100 g. body-weight) }\end{array}$} & \multicolumn{3}{|c|}{$\begin{array}{c}\text { Heart } \\
\text { (g./100 g. body-weight) }\end{array}$} & \\
\hline & & $\begin{array}{l}\text { Ad lib. } \\
\text { control }\end{array}$ & $\begin{array}{l}\text { Inanition } \\
\text { control }\end{array}$ & $\begin{array}{l}\text { Pyridoxin- } \\
\text { deficient }\end{array}$ & $\begin{array}{l}\text { Ad lib. } \\
\text { control }\end{array}$ & $\begin{array}{l}\text { Inanition } \\
\text { control }\end{array}$ & $\begin{array}{l}\text { Pyridoxin- } \\
\text { deficient }\end{array}$ & \\
\hline I $\delta$ & 36 & 0.940 & $1 \cdot 173$ & $1 \cdot 263$ & 0.429 & $0.50 \mathrm{I}$ & 0.442 & $\begin{array}{l}\text { Control trio (no } \\
\text { deoxypyridoxin } \\
\text { given) }\end{array}$ \\
\hline 20 & 36 & $I \cdot 074$ & $1 \cdot 328$ & 2.504 & 0.437 & 0.549 & 0.640 & $\begin{array}{l}\text { Deoxypyridoxin } \\
\text { tube-fed to pyri- } \\
\text { doxin-deficient } \\
\text { rat }\end{array}$ \\
\hline 30 & 54 & 0.953 & $x \cdot 164$ & 2.400 & 0.436 & 0.463 & $0.73 I$ & $\begin{array}{l}\text { Deoxypyridoxin } \\
\text { tube-fed to pyri- } \\
\text { doxin-deficient } \\
\text { rat }\end{array}$ \\
\hline $\begin{array}{l}\text { Arithn } \\
\text { (trios }\end{array}$ & $\begin{array}{l}\text { means } \\
\text { id 3) }\end{array}$ & 1.014 & $1 \cdot 246$ & $2 \cdot 452$ & 0.437 & 0.506 & 0.686 & \\
\hline
\end{tabular}
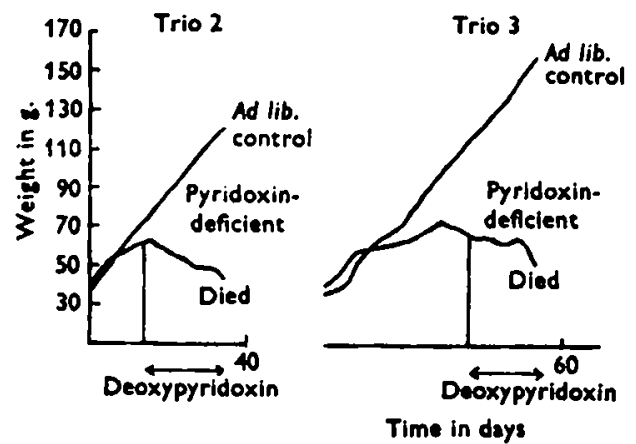

Trio 1

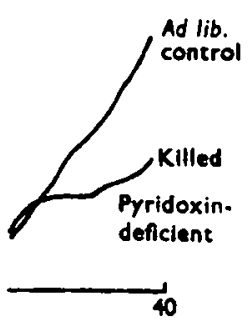

Fig. x. Growth curves of pyridoxin-deficient rato given deoxypyridoxin, of pyridoxin-deficient litter-mate, and of litter-mate ad lib. controls.

the snout were also noted. Both rats died, and their kidneys and hearts were significantly $(P<0.001$ and $P<0.02$ respectively) heavier than the kidneys and heart of the control pyridoxin-deficient rat of trio I (Table 9). Haematuria was not observed in any of these rats. No skin lesions were observed in the control pyridoxin-deficient rat of trio $\mathrm{I}$.

It would seem, therefore, that administration of deoxypyridoxin to hooded rats already receiving a pyridoxin-deficient diet can cause, possibly by destruction of pyridoxin synthesized in the intestine, a striking increase in severity of acrodynia-like skin lesions. Carpenter, Harris \& Kodicek (1948-9) appear to have obtained a similar result by feeding hooded rats $\mathrm{I} \%$ succinylsulphathiazole incorporated in a pyridoxin-deficient diet. 


\section{DISCUSSION}

Haematuria was observed for periods of variable duration in all the pyridoxin-deficient hooded rats (Tables 2-4). Replacement of $5 \%$ margarine by $5 \%$ lard as the source of fat in the diet (Exps. I and 2) did not significantly influence the mean time of onset or the severity of the bleeding (Tables 2 and 3 ), but in rats fed $5 \%$ margarine plus crude linoleic acid $\left(75^{\circ} \mathrm{mg} / \mathrm{I} 00 \mathrm{~g}\right.$. diet) the mean time of onset was delayed (Table 4). The reason for this is unknown, but the animals in Exp. 3 were initially rather heavier than those of Exps. I and 2, and 'storage' of pyridoxin (Cerecedo \& Foy, r942) rather than any possible protective effect of linoleic acid, may have determined the later onset of haematuria. Five of the six ad lib. control rats fed linoleic acid developed haematuria (Table 4). Although Kratzer \& Williams (1948) observed reduction of growth, curable by pyridoxin, in chicks fed linseed-oil meal at a level of $10 \%$ or higher in the diet, and linseed-oil meal is a rich source of linoleic acid, there is no evidence that the ad lib. control rats of Exp. 3 developed pyridoxin deficiency. Growth was unsatisfactory in only one ad lib. control rat and this was probably due to severe haematuria and not to pyridoxin deficiency. Further, none of the inanition-control rats developed haematuria, although the effect of depriving an inanition-control rat of pyridoxin (Table 2, trio E) suggests that these animals might be especially sensitive to lack of pyridoxin. As mentioned above, the linoleic acid used (British Drug Houses Ltd., technical) may have been unsuitable for nutritional studies. However, a direct toxic action is unlikely as the inanition-control rats fed the complete diet plus linoleic acid did not develop haematuria. For the same reason it is unlikely, although possible, that one or more of the vitamin supplements might have been inactivated by contact with the linoleic acid when the diet was made up in bulk, and that this could have been a contributory cause of the haematurias in the ad lib. control rats. Pathological changes were seen in the kidneys of these ad lib. control rats similar to those observed in pyridoxin-deficient rats (Agnew, 1949).

Tables 2-4 show that the incidence of haematuria in the pyridoxin-deficient hooded rats was $100 \%$ (all eighteen animals). However, there may be great variation in the incidence and time of onset of the bleeding. For example, haematuria was observed in four of seven pyridoxin-deficient rats of trios used in studies on antibody production (Agnew \& Cook, 1948-9, Table 3), and killed after 52 days on the deficient diet. Again, haematuria was noted in seven pyridoxin-deficient rats after the diet had been fed for 34, 39, 40, 62, 63, 74 and 75 days respectively (Agnew, 1948-9); the true incidence is not known as trios of rats were killed throughout the experiment after different periods on the diet, but was probably less than $50 \%$.

Haematuria was not observed in any of the pyridoxin-deficient albino rats (Table 5), although red cells were detected microscopically in the urine of the ad lib. and inanition controls of one trio (Table 5, trio B). 'Microscopic haematuria' of variable duration has occasionally been noted in apparently normal rats (Cavelti \& Cavelti, I945; Humphrey, 1948) and no significance is attached to the microscopic haematuria in these control rats. Presumably strain differences were responsible for the failure of the pyridoxin-deficient albino rats to develop haematuria. Smadel \& Swift (I94I) studied the 
effect of administration of anti-kidney serum to three different strains and found that Wistar albino rats were less susceptible than Whelan (usually hooded) or Evans (usually hooded) rats, and it may well be that the factors which determined these differences in susceptibility to anti-kidney serum were operative in the present experiments. Although haematuria was not observed in the pyridoxin-deficient albino rats, the kidneys of these rats were, like those of the pyridoxin-deficient hooded rats, significantly heavier (g./100 g. body-weight) than those of the corresponding inanition and ad lib. controls (Table 8). The hearts also of the pyridoxin-deficient albino and hooded rats were generally significantly heavier (g./100 g. body-weight) than those of the corresponding inanition and ad lib. controls, presumably because of some degree of hypertension. Recent work by Hartroft \& Best (1949), on the development of hypertension in cholinedeficient rats with residual renal damage, is of interest in this connexion.

Only Birch (1938) appears to have observed haematuria in pyridoxin-deficient rats, but bleeding appeared as a terminal symptom after his animals had been about I6-20 weeks on the deficient diet. Also, it is possible that he was not dealing with uncomplicated pyridoxin deficiency.

Although certain pathological changes in the kidneys of the hooded rats with haematuria in Exps. I-3 resemble those reported in the kidneys of rats deprived of essential fatty acids (Borland \& Jackson, 193r), it is unlikely that essential fatty acid deficiency caused the haematuria in the experiments reported here because the ad lib. and inanition controls of Exps. $x$ and 2 did not develop haematuria.

The failure of administration of pyridoxin to influence the duration or severity of the haematuria (Table 2, trio B; Table 3, trios B and C) is interpreted as an indication that irreversible renal damage had occurred. Administration of pyridoxin shortly after the onset of haematuria might have been more effective but it would then be impossible to ascertain that the bleeding would not have disappeared in any case (see Table 2, trio C).

The effect of administration of deoxypyridoxin to hooded rats fed the pyridoxindeficient diet suggests that there may be a direct relationship between the severity of pyridoxin depletion and the weight of the kidneys (Table 9). If the rate of development and severity of acrodynia-like skin lesions are taken as an index of the severity of pyridoxin depletion, and the experiments with deoxypyridoxin seem to justify this assumption, then the albino rats were exposed to a more severe depletion of pyridoxin than the hooded rats. But haematuria was not observed in the pyridoxin-deficient albino rats. It would seem, therefore, that the degree of severity of pyridoxin depletion was not a factor in the present experiments in determining the observed strain differences in susceptibility to the development of haematuria.

A direct relationship is known to exist between the degree of severity of pyridoxin deficiency and the protein content of the diet. In all the experiments reported here the level of casein in the diet was $18 \%$. Kidney hypertrophy has been reported in rats fed high-protein diets (Reader \& Drummond, 1926; Hartwell, 1928; MacKay, 1933). These workers have also shown that the increase in kidney weight could be prevented (Reader \& Drummond, 1926; Hartwell, 1928) or greatly lessened (MacKay, 1933) by increasing the amount of yeast in the diet. It is possible that pyridoxin deficiency, 
produced indirectly by an increase in the percentage of protein in the diet, was responsible for the kidney hypertrophy described by these workers. This hypothesis would conveniently explain the beneficial action of the yeast and also why, in the experiments of Reader \& Drummond (1926), poor growth resulted when a diet containing $70 \%$ of protein was supplemented with only the same proportion $(4 \%)$ of yeast extract that sufficed for good growth with $20 \%$ of protein.

Severe pyelonephritis was observed at post-mortem in two pyridoxin-deficient rats (Table 4, trio E; Table 5, trio E). In two other pyridoxin-deficient rats (Table 2, trio A; Table 3, trio D) a few polymorphonuclear leucocytes were seen in kidney tubules and a diagnosis of mild pyelonephritis was made. The possibility that the haematuria and the renal lesions observed in the pyridoxin-deficient hooded rats might have resulted from pyelonephritis of varying severity had therefore to be considered, especially as Agnew \& Cook (1948-9) had recently confirmed and extended the work of Stoerk \& Eisen (1946), which showed impaired antibody production in pyridoxin-deficient rats. Although spontaneous abscess formation has occasionally been observed in pyridoxin-deficient rats (e.g. Table 4, trio B; and Agnew \& Cook, 1948-9, Table 3, trio 16 ), the poor antibody response of pyridoxin-deficient rats to such antigens as sheep erythrocytes (Stoerk \& Eisen, 1946; Agnew \& Cook, 1948-9) or a killed culture of Bacterium typhosum (Agnew \& Cook, 1948-9) does not necessarily mean that such animals would be more susceptible to infection. Urine cultures from other pyridoxin-deficient rats with haematuria failed to reveal organisms (e.g. Salmonella enteritidis, see Smadel, 1937) commonly associated with outbreaks of infective pyelonephritis in stock rats. In earlier experiments, examination of the kidneys of rats killed shortly after the onset of haematuria did not reveal signs of early pyelonephritis, and bacteria were not seen in Gram-stained sections. Further, pyelonephritis was noted in one of the kidneys of one of the pyridoxin-deficient albino rats, but haematuria was not observed in any of these rats although antibody production was probably impaired. It would seem unlikely that, with the exception of the four rats mentioned above, increased susceptibility to infective pyelonephritis due to pyridoxin deficiency could have accounted for the haematuria and renal lesions observed in these experiments.

\section{SUMMARY}

I. Severe haematuria of variable duration was observed in all of eighteen hooded rats fed a pyridoxin-deficient diet with $5 \%$ margarine, $5 \%$ lard, or $5 \%$ margarine plus $750 \mathrm{mg} . / 100 \mathrm{~g}$. diet of crude linoleic acid. Haematuria was unexpectedly observed in five of six of the ad lib. control hooded rats receiving the crude linoleic acid supplement, and possible reasons for this are discussed. Haematuria was not observed in any of the paired-weighed control hooded rats.

2. Haematuria was not observed in albino pyridoxin-deficient rats, although these rats developed far more severe acrodynia-like skin lesions than pyridoxin-deficient hooded rats. The degree of severity of pyridoxin depletion, as gauged by the rate of development and severity of acrodynia-like skin lesions, did not appear to be the factor determining the observed strain differences in susceptibility to the development of haematuria. 
3. Preliminary experiments suggested that the failure of pyridoxin-deficient hooded rats to develop acrodynia-like skin lesions as severe as those observed in albino rats was due to endogenous biosynthesis of pyridoxin, since administration of deoxypyridoxin to hooded rats already receiving a pyridoxin-deficient diet resulted in the development of severe acrodynia-like skin lesions similar to those hitherto seen only in albino rats.

4. The severity of haematuria did not influence the blood picture, essentially that of microcytosis, of the pyridoxin-deficient hooded rats.

5. Pyridoxin administration did not ameliorate an established haematuria; possible reasons for this apparent anomaly are discussed. Ascorbic acid and rutin, which were tried in one case, were similarly ineffective.

6. Spontaneous infective pyelonephritis resulting from the impaired antibody production in pyridoxin deficiency is not thought to account for the development of haematuria in these experiments.

7. Irrespective of strain, and hence irrespective of the presence of haematuria, the hearts and kidneys of the pyridoxin-deficient rats were usually significantly heavier (g./100 g. body-weight) than those of corresponding paired-weighed and ad lib. control rats.

Part of this work was done during the tenure of a full-time Agricultural Research Council scholarship.

I wish to thank Mr M. H. Quenouille of the Statistics Department, Marischal College, Aberdeen, and $\mathrm{Mr} \mathrm{A}$. W. Boyne of this Institute, for statistical analysis of much of the data presented. Grateful acknowledgement is also made to Mr G. Porter and his staff for their skilful and careful handling of the animals, and Mr E. A. S. Rattray for his expert technical assistance in many aspects of this work.

Generous supplies of deoxypyridoxin were obtained through the kindness of Dr F. Wrigley of Roche Products Ltd., and Dr Karl Folkers of Merck and Co., Rahway, New Jersey. Rutin tablets were obtained through the courtesy of Messrs Allen and Hanbury.

\section{REFERENCES}

Agnew, L. R. C. (1948-9). Brit. F. Nutrit. 2, iv.

Agnew, L. R. C. (1949). Unpublished results.

Agnew, L. R. C. \& Cook, R. (1948-9). Brit. F. Nutrit. 2, 32 I.

Birch, T. W. (1938). Y. biol. Chem. 124, 775.

Borland, V. G. \& Jackson, C. M. (1931). Arch. Path. xI, 687.

Carpenter, K. J., Harris, L. J. \& Kodicek, E. (1948-9). Brit. $\mathcal{~ F . ~ N u t r i t . ~ 2 , ~ v i i . ~}$

Carpenter, K. J. \& Kodicek, E. (1948-9). Brit. F. Nutrit. 2, ix.

Cavelti, P. A. \& Cavelti, E. S. (1945). Arch. Path. 40, 163.

Cerecedo, L. R. \& Foy, J. R. (1942). F. Nutrit. 24, 93.

Evans, C. L. (1945). Starling's Principles of Human Physiology, 9th ed. London: Churchill.

Hartroft, W. S. \& Best, C. H. (1949). Brit. med. F. i, 423.

Hartwell, G. A. (1928). Biochem. Y. 22 , 1212.

Humphrey, J. H. (1948). F. Path. Bact. 6o, 211 .

Kratzer, F. H. \& Williams, D. E. (1948). F. Nutrit. 36, 297.

MacKay, E. M. (1933). Amer. F. Physiol. ro6, 571.

Reader, V. \& Drummond, J. C. (1926). Biochem. J. 20, 1256.

Smadel, J. E. (1937). 7. exp. Med. 65, 541.

Smadel, J. E. \& Swift, H. F. (1941). \%. exp. Med. 74, 345.

Stoerk, H. C. \& Eisen, H. N. (1946). Proc. Soc. exp. Biol., N.Y., 62, 88. 